NBER WORKING PAPER SERIES

\title{
THE EFFECT OF WEIGHT ON LABOR MARKET OUTCOMES: AN APPLICATION OF GENETIC INSTRUMENTAL VARIABLES
}

\author{
Petri Böckerman \\ John Cawley \\ Jutta Viinikainen \\ Terho Lehtimäki \\ Suvi Rovio \\ Ilkka Seppälä \\ Jaakko Pehkonen \\ Olli Raitakari \\ Working Paper 22200 \\ http://www.nber.org/papers/w22200
NATIONAL BUREAU OF ECONOMIC RESEARCH
1050 Massachusetts Avenue
Cambridge, MA 02138
April 2016

The Young Finns Study has been financially supported by the Academy of Finland: grants 134309 (Eye), 126925, 121584, 124282, 129378 (Salve), 117787 (Gendi), and 41071 (Skidi), the Social Insurance Institution of Finland, Kuopio, Tampere and Turku University Hospital Medical Funds (grant 9N035 and X51001), Juho Vainio Foundation, Paavo Nurmi Foundation, Finnish Foundation of Cardiovascular Research and Finnish Cultural Foundation, Tampere Tuberculosis Foundation and Emil Aaltonen Foundation. The use of linked data is supported by the Palkansaaja Foundation. Two of the authors acknowledge the financial support from the Yrjö Jahnsson foundation (grants 6646 and 6664). We thank Jani-Petri Laamanen for helpful discussant comments. Cawley thanks the Robert Wood Johnson Foundation for an Investigator Award in Health Policy Research. We thank Barton Willage for research assistance. The views expressed herein are those of the authors and do not necessarily reflect the views of the National Bureau of Economic Research.

NBER working papers are circulated for discussion and comment purposes. They have not been peer-reviewed or been subject to the review by the NBER Board of Directors that accompanies official NBER publications.

(C) 2016 by Petri Böckerman, John Cawley, Jutta Viinikainen, Terho Lehtimäki, Suvi Rovio, Ilkka Seppälä, Jaakko Pehkonen, and Olli Raitakari. All rights reserved. Short sections of text, not to exceed two paragraphs, may be quoted without explicit permission provided that full credit, including $(\odot$ notice, is given to the source. 
The Effect of Weight on Labor Market Outcomes: an Application of Genetic Instrumental Variables

Petri Böckerman, John Cawley, Jutta Viinikainen, Terho Lehtimäki, Suvi Rovio, Ilkka Seppälä, Jaakko Pehkonen, and Olli Raitakari

NBER Working Paper No. 22200

April 2016

JEL No. D62,I1,I12,J01,J24,J3,J7

\section{ABSTRACT}

The increase in the prevalence of obesity worldwide has led to great interest in the economic consequences of obesity, but valid and powerful instruments for obesity, which are needed to estimate its causal effects, are rare. This paper contributes to the literature by using a novel instrument: genetic risk score, which reflects the predisposition to higher body mass index across many genetic loci. We estimate IV models of the effect of BMI on labor market outcomes using Finnish data that have many strengths: genetic information, measured body mass index, and administrative earnings records that are free of the problems associated with non-response, selfreporting error or top-coding.

The first stage of the IV models indicate that genetic risk score is a powerful instrument, and the available evidence from the genetics literature is consistent with instrument validity. The results of the IV models indicate weight reduces earnings and employment and increases social income transfers, although we caution that the results are based on small samples, and are sensitive to specification and subsample.

Petri Böckerman

Turku School of Economics

Finland

petri.bockerman@labour.fi

John Cawley

2312 MVR Hall

Department of Policy Analysis and Management

and Department of Economics

Cornell University

Ithaca, NY 14853

and NBER

JHC38@ cornell.edu

Jutta Viinikainen

Jyväskylä University

School of Business and Economics

Finland

jutta.viinikainen@jyu.fi

Terho Lehtimäki

University of Turku

terho.lehtimaki@uta.fi
Suvi Rovio

Turku, Finland

suvi.rovio@utu.fi

Ilkka Seppälä

University of Tampere

Finland

ilkka.seppala@uta.fi

Jaakko Pehkonen

Jyväskylä University

School of Business and Economics

Finland

jaakko.k.pehkonen@jyu.fi

Olli Raitakari

University of Turku and

Turku University Hospital

Finland

olli.raitakari@utu.fi 


\section{Introduction}

The prevalence of obesity, defined as a body mass index (or BMI, which is calculated as weight in $\mathrm{kg}$ divided by height in $\mathrm{m}$ squared) of 30 or higher, has risen dramatically in many countries in the past several decades (NCD Risk Factor Collaboration, 2016; OECD, 2014). Economists have shown considerable interest in the economic consequences of obesity, in particular whether obesity lowers wages or reduces the probability of employment (see the reviews in Averett, 2011; Averett, 2014; and Cawley, 2015). Obesity could result in worse labor market outcomes for several reasons; e.g. it has long been established that obesity worsens health $(\mathrm{Hu}$, 2008) which may lower productivity and thus wages, or there may be obesity-related discrimination in the labor market (Puhl, 2011; Rooth, 2009).

Correlations between weight and labor market outcomes are difficult to interpret. They reflect not only any impact of weight on labor market outcomes, but also any reverse causality that would arise if low income results in weight gain (see e.g. Schmeiser, 2009 and Akee et al., 2013), and influence of omitted variables (e.g. rate of time preference; people who are myopic may be heavier and also lowerproductivity workers).

Several studies have used the method of instrumental variables to estimate the causal effect of weight on labor market outcomes. Most have instrumented for respondent weight using the weight of a biological relative; e.g. Cawley (2004), Brunello and D’Hombres (2007), Kline and Tobias (2008), and Lindeboom et al. (2010). This approach takes advantage of the substantial genetic variation in weight; genetics studies estimate a strong heritable component of BMI, roughly $40-70 \%$

(Barsh et al., 2000; Pietilainen et al., 1999; Locke et al., 2015). 
The gradually increasing availability of genetic data has raised the possibility of more accurate instruments that measure a genetic predisposition to obesity. In theory, information about individual genes can be used as instruments, taking advantage of the natural experiment known as Mendelian Randomization, which refers to the random assignment of an individual's genotype at conception (von Hinke Kessler Scholder et al., 2016; Tyrrell et al. 2016). One study (Norton and Han, 2008) used genetic information as an instrument for weight to estimate the effect of weight on labor market outcomes, although the specific approach was later called into question as relatively weak and likely invalid (Cawley, Han, and Norton, 2011; von Hinke Kessler Scholder et al., 2016). The problem is that the six single nucleotide polymorphisms (SNPs) $)^{1}$ that were used as instruments all influenced the neurotransmitters dopamine and serotonin and thus were only weakly associated with weight and were associated with many other things that could affect labor market outcomes (such as education and depression).

The contribution of this study is as follows. The most important contribution is that we advance the literature by estimating IV models of obesity on labor market outcomes using genetic instruments. The specific instrument used in this paper is based on the findings of the genetics literature; specifically, our instrument is a genetic risk factor score that takes into account 32 SNPs that have robustly and significantly $\left(\mathrm{p}<1.0 \times 10^{-8}\right)$ been found to influence obesity in genome-wide association studies involving very large population samples. This makes for a stronger instrument. Moreover, the genetics literature fails to find a link between these SNPs and other, non-obesity-related characteristics that could affect labor market outcomes.

\footnotetext{
${ }^{1}$ Places where DNA differ between people are called polymorphisms, and a single nucleotide polymorphism or SNP is a single base-pair variation in DNA. Humans have two copies of each chromosome, so they have two alleles, or versions, of each SNP that may be the same (homozygous) or different (heterozygous). See Appendix A of von Hinke Kessler Scholder et al. (2012).
} 
Thus, the instrument is also arguably more valid than past genetic instruments used in this context. Moreover, a recent study used it as an example of a powerful and valid application of genes as instruments (von Hinke Kessler Scholder et al., 2016).

This study has two other advantages over the previous literature on the effect of weight on labor market outcomes. First, it uses data on measured weight and height instead of self-reported weight and height; thus, we avoid the problems arising from reporting error in weight such as inefficiency and bias (see Cawley, Maclean et al., 2015; Courtemanche et al., 2015). Second, this paper uses administrative data on earnings, which likewise avoids problems associated with refusal to report, and reporting error in, wages and salaries.

We use data from Finland. The prevalence of obesity in Finland is $20.9 \%$ among adult men and 22.3\% among adult women ( $\mathrm{Ng}$ et al., 2014). This is roughly two-thirds the prevalence of obesity in the U.S. but is similar to that in other Western European countries. The Finnish labor markets are comparable to those of other countries in Western Europe, in that the employment rate and female labor market participation are high, with similar labor market institutions such as collective wage bargaining and binding minimum wages. Moreover, previous studies have established that there is a significant negative correlation between weight and labor market outcomes in Finland (Sarlio-Lähteenkorva et al., 2004; Johansson et al., 2009), as there is for many other countries of Western Europe (e.g. Brunello and D'Hombres, 2007; Averett, 2014).

\section{Data}

We link data from three sources: 1) the Cardiovascular Young Finns Study (YFS); 2) the Finnish Longitudinal Employer-Employee Data (FLEED) of Statistics 
Finland (SF); and 3) the Longitudinal Population Census (LPC) of SF. The merge is executed using unique personal identifiers, which is exact matching; i.e. there are no misreported ID codes. As a result, this paper avoids problems created by errors in record linkages (e.g. Ridder and Moffitt, 2007).

The Cardiovascular Young Finns Study (YFS) began in 1980 with the goal of examining how youthful health behaviors, as well as biological and psychological factors, contribute to the risk of cardiovascular diseases in adulthood. ${ }^{2}$ Subjects in six age cohorts (aged 3, 6, 9, 12, 15 and 18 years) were randomly chosen from the five university hospital districts of Finland using the national population register (Raitakari et al. 2008). ${ }^{3}$ The sample is relatively small - 3,596 persons participated in the study at baseline - but the richness of the data are a strong offsetting advantage. Eight waves of data have been collected, starting with baseline in 1980 and most recently in 2011-12, with response rates between 60 and $80 \% .{ }^{4}$ We use data from the 2001, 2007 and 2011 waves, because we have labor market data only for 1990-2012 (as we explain below). The 1992 wave of YFS has relatively few observations, because most of the sample was too young for full-time employment.

The YFS collects data through questionnaires, physical measurements and blood tests. Weight and height were measured in all waves of the YFS. All anthropometric measurements, including those for weight and height, were conducted by medical professionals at local health centers.

In 2009, genome-wide association studies (GWAS) were performed for YFS subjects using the $670 \mathrm{~K}$ Illumina platform (Sanger Institute, UK). Variation in over

\footnotetext{
${ }^{2}$ YFS is the largest running follow-up study in Europe that evaluates cardiovascular risk factors from childhood to adulthood.

${ }^{3}$ Finland is divided into 20 hospital districts, five of which are university hospital districts.

${ }^{4}$ For more information on the study design of the Cardiovascular Risk in Young Finns Study, see: $\underline{\text { http://youngfinnsstudy.utu.fi/studydesign.html }}$
} 
670,000 known single nucleotide polymorphisms (SNPs) was measured from 2,450 study subjects. Imputation for up to 2.5 million SNPs was performed using information on Hapmap 2 by using MACH. ${ }^{5}$ All the SNPs were imputed with excellent imputation quality ( $\left.\mathrm{MACH}^{2}>0.8\right)$.

We utilize a genetic risk score for BMI that is based on the 32 SNPs that were found to be associated genome-wide significantly $\left(\mathrm{p}<1.0 \times 10^{-8}\right)$ with BMI by Speliotes et al. (2010). The genetic risk score is equal to the sum of the alleles in all of the 32 SNPs that put one at elevated risk of high BMI. This risk score has two major advantages as an instrument: first, it is more powerful (explains more variation in weight) than any of the SNPs individually, and second, it is arguably more valid because it reduces the risk that an alternative biological pathway (pleiotropy) in any individual SNP will bias the IV results (Palmer et al., 2012; Davey Smith, 2011). We describe later the evidence from the genetics literature regarding the pleiotropy of the individual SNPs.

The second dataset that we use, the Finnish Longitudinal Employer-Employee Data (FLEED), is the source for labor market outcomes such as employment status, salary, and other income, for 2001 to 2012 . FLEED data come directly from tax and other administrative registers that are collected and/or maintained by SF. Such register-based data have much less measurement error than self-reports from surveys; e.g. the income data in FLEED do not suffer from underreporting or recall error, nor are they top coded. This accuracy increases the efficiency of the estimates, which is particularly important for relatively small samples such as the YFS. The third dataset that we use, the Longitudinal Population Census (LPC), is the source of information

\footnotetext{
${ }^{5}$ For more information on the MACH method of imputation, see: http://www.sph.umich.edu/csg/abecasis/mach/
} 
on parental education. The linkage of both FLEED and LPC to the YFS data is performed using unique personal identifiers that are available for both parents and their children.

\section{Methods}

We estimate regressions of the following form:

$$
Y_{i}=\alpha+W_{i} \beta+X_{i} \gamma+\varepsilon_{i}
$$

We examine four labor market outcomes $Y$. Out of a concern that short-term, cross-sectional measures, such as yearly earnings or current employment status contain idiosyncratic components that diminish the precision of the estimates (cf. Dahl et al., 2011), $Y$ is usually the average of the values over the period of the data (2001 to 2012), although we examine year-specific outcomes as a robustness check.

The first labor market outcome we examine is the logarithm of the average of the individual's annual wage and salary earnings over the period that most respondents were of working age: 2001-2012.

The second dependent variable we examine is labor market attachment; specifically: the share of years employed during 2001-2012, with employment status in a year classified by the individual's status in the last week of the year in FLEED. Retirement is not an issue for this sample; the YFS participants are between 35 and 50 years old in $2012 .^{6}$

The third dependent variable we examine is an indicator variable for whether the respondent received any social income transfers between 2001 and 2012. The

\footnotetext{
${ }^{6}$ We considered examining an additional outcome: receipt of disability pension. This information is included in the FLEED for each year, but YFS subjects are still relatively young during our observation window of 2001-2010 (48 years old at the most) and thus receipt of disability pension is almost nonexistent among YFS subjects.
} 
fourth and final dependent variable is the logarithm of the average of the individual's annual social income transfers. Social income transfers include unemployment benefits and disability payments. ${ }^{7}$ We examine their receipt for two reasons: first, social income transfers are an important component of total income in Finland, a welfare state, and second, the amount of social income transfers is informative about negative externalities related to obesity. For both wages/earnings and social income transfers, the values in each year are converted to constant (inflation-adjusted) values using the consumer price index (base year 2000) before the average is calculated.

Our regressor of interest is weight $W$. Our primary measure of weight is body mass index or BMI, which is calculated as a person's weight in kilograms divided by height in meters squared - higher values indicating increased adiposity. In our primary models, we use BMI measured in 2001, although as a robustness check we also use BMI from 2007 and 2011. As robustness checks, we also estimate models in which the measure of weight is an indicator variable for obesity (defined as a BMI $>=30$ ) and weight in kilograms (controlling for height in meters). BMI and weight in $\mathrm{kg}$ are limited measures of fatness because they ignore body composition (see, e.g. Burkhauser and Cawley, 2008). For this reason, we also use waist-to-hip ratio (WHR), a measure of central adiposity (i.e., fatness around the midsection).

The model also controls for other potential determinants of wages with the vector of regressors $X$. These include: indicator variables for birth month and birth year, gender, and height. Typically, wage equations include education as a regressor (Mincer, 1974). In this case that practice is questionable, as obesity has been shown to reduce academic performance and be associated with lower educational attainment,

\footnotetext{
${ }^{7}$ We exclude parental leave benefits from social income transfers because they are not a "negative indicator" in the same way as unemployment benefits and disability payments.
} 
although findings are mixed (Sabia, 2007; von Hinke Kessler Scholder et al., 2012). As a precaution, we omit respondent education from the set of regressors and instead control for a measure of parental education: whether each parent has obtained at least some university education (based on LPC data from 1980).

Wage equations sometimes include controls for cognitive ability, when the data are available. Again, however, there is evidence that obesity lowers achievement test scores (Sabia, 2007; Averett and Stifel, 2010). Another consideration in our case is power; tests of cognitive ability were administered to only a subset of the YFS, so to control for it we would have to restrict our sample. For these two reasons we do not control for cognitive ability in our main regressions but we do control for it as an extension (see Appendix A1 for description of the measures for cognitive skills).

The relatively small sample size of the YFS limits the statistical power when estimating the model for subsamples. For this reason, the main models in our paper are estimated for men and women pooled, and thus represent the average effect across both sexes. However, previous studies of the impact of weight on labor market outcomes have often found differences by gender (e.g. Cawley, 2004), so as an extension we also estimate models separately by gender.

We first estimate equation (1) using ordinary least squares (OLS) in order to estimate the conditional correlation of weight with labor market outcomes. ${ }^{8}$ However, these correlations reflect not only any causal effect of weight on wages, but also potentially reverse causality and the influence of omitted variables that may be correlated with both weight and labor market outcomes.

\footnotetext{
${ }^{8}$ For the binary outcome of receiving any social income transfers we estimate linear probability models.
} 
In order to estimate the causal effect of body weight on labor market outcomes, we estimate models of instrumental variables (IV) in which our IV is the genetic risk factor score for BMI. ${ }^{9}$ It is estimated that $40-70 \%$ of inter-individual variability in BMI is due to genetic factors (e.g. Locke et al., 2015), so the genetic risk factor score has the potential to be a powerful instrument.

The risk score we use is based on the 32 SNPs identified as linked to BMI in Speliotes et al. (2010). The score equals the number of alleles associated with an elevated risk of high BMI; because each person has at most two such alleles for each of the 32 SNPs, the score ranges from 0 to 64 . Speliotes et al. (2010) report that the mechanisms by which these SNPs affect weight are through: 1) regulators of appetite or energy balance; and 2) insulin secretion or response. Speliotes et al. (2010) estimate that, collectively, the 32 loci that constitute our risk score explain $1.45 \%$ of the inter-individual variation in BMI. ${ }^{10}$ (Even though it is estimated that $40-70 \%$ of inter-individual variation in BMI is due to genetic factors, all currently-identified SNPs explain just a few percentage points of the variation; in other words, the vast majority of genetic variability in BMI remains unexplained; see, e.g., Locke et al., 2015.) Each one-unit increase in the genetic risk factor score was associated with an increase in BMI of 0.17 units, or roughly one-half of a kilogram of weight for an average-sized adult (Speliotes et al., 2010). This same instrument (an unweighted risk score based on the 32 SNPs associated with obesity by Speliotes et al., 2010) was also used in von Hinke Kessler Scholder (2016) as an example of a valid and powerful

\footnotetext{
${ }^{9}$ For all outcomes, the IV model is two-stage least squares.

${ }^{10}$ Speliotes et al. (2010) reports that the SNP with the greatest explanatory power for BMI is FTO (which explains $0.34 \%$ of variation in BMI), and that having the risky allele for FTO is associated with $20.3 \%$ greater odds of obesity. We have also estimated models in which the IV is a genetic risk score in which each SNP is weighted based on their effect size in the meta-analysis; this was no more powerful than the unweighted genetic risk score.
} 
application of genes as instruments, and to estimate the effect of fat mass on academic achievement and blood pressure.

A threat to the validity of genetic instruments is pleiotropy - genes having more than one function (see, e.g., von Hinke Kessler Scholder, 2016; Cawley, Norton, and Han, 2011). For example, if the same genes associated with higher weight were also associated with unrelated traits or conditions that affect labor market outcomes, then those genes are invalid instruments because the exclusion restriction is violated.

We investigate this possibility two ways. First, we check whether, in the genetics literature, the genes significantly associated with BMI are also significantly associated with other possible determinants of labor market outcomes. Locke et al. (2015) and Speliotes et al. (2010) search the genetics literature for evidence of any pleiotropy of the BMI-related SNPs. Of the 32 SNPs linked to BMI, four are also associated with either Type 2 diabetes, fasting glucose, fasting insulin, or insulin resistance, but this is not surprising because excess fat (by secreting the hormone resistin) causes insulin resistance and thus diabetes ( $\mathrm{Hu}, 2008)$; thus, these can be considered part of the total effect of obesity. Three of the 32 SNPs are also associated with height (Speliotes et al., 2010), so we control for height in all of our models. Two of the 32 SNPs are associated with age of onset of menstruation (menarche), but this too is related to fatness (Kaplowitz, 2008; Wang, 2002) and thus is not a threat to validity. Two of the 32 SNPs are linked to cholesterol levels and one to blood pressure; both of these conditions are strongly associated with obesity (e.g. Hu, 2008) and thus can be considered part of the effect of obesity, but as an extension we reestimate our models controlling for genetic risk scores for total cholesterol, triglycerides, and blood pressure. In summary, the few other phenotypes that the obesity-related SNPs are associated with tend to be obesity-related comorbidities; the 
exception is height, which we are able to control for directly. ${ }^{11}$ Thus, findings from the genetics literature tend to be consistent with the identifying assumption. ${ }^{12}$

As a second check of the validity of the genetic instruments, we follow McClellan et al. (1994) and divide our sample into those with an above-average and below-average value of the instrument, and test whether the two groups significantly differ in their observable characteristics that are likely correlated with the secondstage outcome. It is impossible to confirm the null hypothesis that the instrument is uncorrelated with the second-stage error term, but a lack of correlation between the instrument and observed variables would be consistent with the exclusion restriction.

\section{Empirical Results}

\section{Summary Statistics}

Appendix Table A2 contains summary statistics for our regression sample. In 2001, the mean weight of respondents was $74.7 \mathrm{~kg}$ and the mean BMI in 2001 was 25.1. The average annual earnings between 2001 and 2012 are $€ 24,528$, and the average annual social income transfers are $€ 1,846$. The average share of years spent employed between 2001 and 2012 is $85.7 \%$. Relatively few have college-educated mothers $(7.2 \%)$ or college-educated fathers $(10.2 \%)$, which is true for these birth-year cohorts in Finland as a whole (OECD, 2015). The average genetic risk score for BMI is 29.1 , with a maximum in this sample of 41.8 , out of a possible maximum of 64 (2 alleles for each of 32 SNPs).

\footnotetext{
${ }^{11}$ In contrast, there was abundant evidence that the dopamine-related genes used as IVs for weight in the previous literature were only very weakly associated with weight and were associated with a wide range of conditions that were unrelated to weight and thus were a threat to validity; see the discussion in Cawley, Han and Norton (2011).

${ }^{12}$ A spreadsheet listing the SNPs associated with these conditions, and the relevant studies, is available upon request.
} 


\section{OLS Estimates}

OLS estimates are presented in Column 1 of Table 1. In OLS regressions, a one-unit increase in $\mathrm{BMI}$ is associated with: $0.07 \%$ lower average earnings, $0.2 \%$ fewer years spent employed, 0.1 percentage point lower probability of any social income transfers, and $1.2 \%$ lower social income transfers, none of which are statistically significant.

\section{IV: Power and Validity}

Because we seek to estimate the causal effect of BMI on labor market outcomes, we next estimate IV models.

The genetic risk score for BMI is a powerful instrument for BMI. In the first stage of IV, the F statistic on the instrument is 36.59 in the earnings regression, 39.94 in the employment regression, and 36.59 in the social income transfers regressions, all of which far exceed the minimum standard of $F=10$ suggested in Staiger and Stock (1997). ${ }^{13}$ In the first stage of IV, the marginal R-squared of the genetic risk score is 0.0167, which implies that the risk score explains $1.67 \%$ of the variation in BMI; this is similar to the estimate in Sperliotes et al. (2010) that the risk score explains $1.77 \%$ of inter-individual variation in BMI in their sample.

In order to examine the validity of the genetic instruments, Appendix Table A3 presents means of the observed variables for those with above- and below-average values of the BMI genetic risk score, and tests for equality of the means. As expected, those with above-average genetic risk factor scores have a significantly higher BMI (by 0.92 units); this is consistent with the instrument being powerful. The table also

\footnotetext{
${ }^{13}$ We have also estimated IV models that use both the genetic risk score and its square as instruments. The first-stage F-statistics in these models are lower (roughly 18), and the results are similar, so we continue to estimate models that simply use the level of the risk score as the IV.
} 
shows that those with a higher genetic risk score for obesity have significantly lower earnings, which is consistent with BMI worsening labor market outcomes.

Regarding validity, there is no significant difference between those with high and low genetic risk scores in terms of marital status, mother's income, father's income, mother's education, or father's education. There is a significant difference in two aspects of cognitive performance: rapid visual information processing and spatial working memory. The literature searches of Speliotes et al. (2010) and Locke et al. (2015) did not turn up evidence of a link between the BMI-related SNPs and intelligence. There is also some evidence that obesity worsens academic test scores (Sabia, 2007; Averett and Stifel, 2010), although von Hinke Kessler Scholder et al. (2012) could not reject the null of no effect. In case these SNPs are associated with intelligence through mechanisms other than weight, we, as a robustness check, estimate a model that controls for the measures of cognition. (We do not control for it in all models because it may be affected by weight, and we only have cognitive scores for a subset of the already-small sample.)

\section{Estimates}

The coefficients from the IV models are presented in column 2 of Table 1. They indicate that a one-unit increase in $\mathrm{BMI}$ is associated with $6.6 \%$ lower wages and $1.7 \%$ fewer years employed. The standard deviation of BMI in the YFS data is 4.29; thus, a two-standard deviation increase in BMI is associated with $56.6 \%$ lower wages and $14.59 \%$ fewer years employed.

A one-unit increase in BMI is also associated with a 2.9 percentage point (3.5\%) higher probability of receiving any social income transfers, and a $24.8 \%$ increase in the amount of social income transfers. 
Table 2 presents results of reduced-form models that regress labor market outcomes on the instrument (BMI genetic risk score) directly, controlling for the same set of regressors as earlier. The results are consistent with those of the IV models. Raising the genetic risk score by one (meaning that an individual has one additional allele that raises their risk of weight gain) is associated with $1.1 \%$ lower earnings, $0.3 \%$ fewer years of employment, a 0.5 percentage point $(0.6 \%)$ higher probability of receiving any social income transfers, and $4.1 \%$ higher amount of social income transfers, all of which are statistically significant.

\section{Extensions}

We estimate several additional models to assess the robustness of the results.

\section{Extension 1: Estimate Models Separately by Wave}

In our main results we examine average labor market outcomes over the period 2001-2012 in order to minimize the influence of idiosyncratic variation that would diminish the precision of the estimates (cf. Dahl et al., 2011). As an extension we estimate models for each wave of the YFS separately $(2001,2007,2011)$, regressing the labor market outcome for that year on BMI from that year and other characteristics in that year (the exception is parental education, which is recorded on a single date); these results are presented in Table 3.

With the smaller samples and reduced power that comes from examining each wave separately, only one of the wave-specific estimates is statistically significant. The IV model indicates that a one-unit increase in BMI lowers earnings by $17.9 \%$ in 2001, compared to $6.6 \%$ over $2001-2012$. Both results are statistically significant at a $10 \%$ level. The estimated effect of BMI on employment is very similar for 2001 
$(-2.1 \%)$ and 2001-2012 (-1.7\%), but the former is not statistically significant whereas the latter is.

Although the point estimates in Table 3 are not significantly different from those in Table 1, some are of the opposite sign. There are several possible explanations for the difference in point estimates. For example, it could be the result of idiosyncratic variation in labor market outcomes in a single year. Conversely, contemporaneous weight (used in the wave-specific regressions) may be more relevant than one's historic weight to outcomes in that year.

\section{Extension 2: Control for Genetic Predisposition to Obesity-Related Illnesses}

A general concern about using genetic markers as IVs is that genes may affect multiple things (pleiotropy). As an extension we control for the genetic risk score for blood pressure, total cholesterol, and triglycerides (International Consortium for Blood Pressure Genome-Wide Association Studies, 2011; Teslovich et al., 2010). Table 4 shows that the resulting IV estimates are very similar after we control for these additional genetic risk scores. For example, the IV models indicate that a oneunit increase in BMI reduces log average wages by $6.6 \%$ when we do not control for the other risk scores, and by $6.7 \%$ when we do. A one-unit increase in BMI reduces years spent employed by $1.7 \%$ when we do not control for the other genetic risk scores, and by $1.5 \%$ when we do. Controlling for other genetic risk scores likewise has only a small impact on the IV coefficient on BMI in the regressions concerning social income transfers. 


\section{Extension 3: Control for Cognitive Ability}

In the YFS, measures of cognitive skills are available for only a subset of the sample $(1,339$ out of 2,062). In the main results of this paper, we exclude cognitive skills from the set of regressors because they may be affected by obesity (e.g. Sabia 2007) and in order to avoid losing observations and thus statistical power. However, as an extension we estimate models in which we control for the five measures of cognitive performance: 1) overall cognitive performance 2) visual and episodic memory and visuospatial associative learning; 3) reaction time; 4) rapid visual information processing; and 5) spatial working memory. The results are presented in Table A4.

In each case, the point estimate of the coefficient on BMI is smaller in absolute magnitude. In three of the four cases, the coefficient is no longer statistically significant. The coefficient on BMI in the social income transfers regression remains significant, implying that a one-BMI unit increase raises social income transfers by $20.9 \%$.

\section{Extension 4: Estimate Models Separately by Sex}

Because of the relatively small sample size of the YFS, the main models in this paper were estimated for men and women pooled. However, previous studies of weight and labor market outcomes often found differences by sex; for example, there tends to be a greater wage penalty for excess weight among women than men in the U.S. (Cawley, 2004) and Finland (Johansson et al., 2009). For this reason, as an extension we estimate models separately for men and women; see Appendix Tables A5 (men) and A6 (women). Interestingly, the genetic risk score is a more powerful instrument for men (F of 29-30) than women (F of 9-12). As found in earlier studies of weight and wages, the point estimate of the IV coefficient on BMI is larger for 
women than men; specifically, a one-unit increase in BMI is associated with $10.5 \%$ lower wages for women compared to $4.8 \%$ lower wages for men. Neither is statistically significant, however, presumably because of the smaller sample sizes (1,109 women and 929 men).

The point estimates of the IV coefficient on BMI in the employment regressions are similar for women and men; a one-unit increase in BMI lowers the time spent working by $1.9 \%$ for women and $1.7 \%$ for men; neither is statistically significant.

The impact of BMI on social welfare transfers is positive, large, and statistically significant for men; a one-unit increase in BMI increases social welfare transfers by $26.6 \%$. For women, the estimate is similar, $30.0 \%$, but is not statistically significant. However, a one-unit increase in BMI raises the probability of receiving any social income transfers by 5.2 percentage points (5.9\%) among women.

\section{Extension 5: Alternate Measures of Fatness: Obesity, Kg, Waist-to-Hip Ratio}

As an extension, we estimate models for additional measures of fatness: an indicator variable for obesity (BMI $>=30$ ), weight in kilograms (controlling for height in meters), and waist-to-hip ratio (WHR). WHR is a measure of central adiposity, i.e. fatness around the midsection. As a result, it is more accurate than BMI at predicting adverse health consequences of fatness such as cardiovascular disease, diabetes, and mortality (Hu, 2008; Heid et al., 2010). WHR is also a measure of attractiveness; a low WHR is perceived as more attractive in women and a higher WHR is perceived as more masculine for men (e.g. Singh, 1993; Pazhoohi and Liddle, 2012), and thus any labor market discrimination on the basis of appearance may be more highly 
correlated with WHR than BMI. Results are presented in Appendix Tables A7 (obesity), A8 (kg) and A9 (WHR).

Column 1 in each Table presents results from OLS models. Interestingly, although the OLS coefficients on BMI were not statistically significant (in Table 1), the OLS coefficients on several of the alternate measures of weight are statistically significant. For example, obesity is associated with $13.5 \%$ lower wages and 3.2\% fewer years employed (Appendix Table A7), and a larger waist-to-hip ratio is associated with lower earnings, less employment, and a larger amount of social income transfers received (Appendix Table A9).

We use BMI genetic risk score as an instrument for the indicator for obesity and for weight in $\mathrm{kg}$ (the F statistics far exceed 10 in each case). Appendix Table A7 presents IV results for the indicator for obesity. Results are generally consistent with the IV models for BMI: obesity reduces earnings (by an implausibly large amount $102.8 \%$ ) and reduces the time spent employed by $26.6 \%$. The IV estimates also indicate that obesity raises the probability of receiving social income transfers by $45.7 \%$ and their amount by $386.7 \%$.

Appendix Table A8 presents results for weight in $\mathrm{kg}$. Again, the results are consistent with the models for BMI. The BMI risk score is a powerful IV for weight in $\mathrm{kg}$ (F of 37-41). The IV models indicate that an additional $10 \mathrm{~kg}$ of weight reduces earnings by $22 \%$, reduces the time spent employed by $6 \%$, raises the probability of receiving social income transfers by $10 \%$ and the amount of such transfers by $81 \%$.

We instrument for WHR using a different genetic risk score - one that is based on 16 known susceptibility loci for WHR (Heid et al., 2010). However, the genetic risk score for WHR is not a sufficiently powerful instrument for WHR; i.e. the F statistic in the first stage of IV is below 10 (specifically, between 5 and 6). Adding 
the square of the waist-hip score as an additional instrument does not appreciably raise the F statistic. The genetics literature suggests that WHR is $22 \%-61 \%$ heritable (Heid et al., 2010); this is somewhat lower than the heritability of BMI (40-70\%, see Locke et al., 2015) but it is still sufficiently high that one would expect a complete genetic risk score for WHR to be a powerful instrument. The most likely explanation is that most of the SNPs that affect WHR have not yet been identified. ${ }^{14}$

Results for the IV models of WHR are provided in Appendix Table A9. Although WHR was significantly correlated with labor market outcomes and the amount of social income transfers in the OLS models, in IV models the IV coefficients on WHR are not statistically significant (although the point estimates of the IV coefficients are much larger than those of the OLS coefficients).

In order to investigate the relative importance of BMI and WHR for labor market outcomes, we estimated reduced-form regressions of labor market outcomes on both the genetic risk score for BMI and the genetic risk score for WHR. The results are contained in Appendix Table A10. For all four outcomes, a higher genetic risk score for BMI is associated with worse labor market performance. In addition, those with a high genetic risk score for WHR spend fewer years employed and receive more social income transfers; WHR risk score is not correlated with earnings or the probability of receiving social income transfers. Thus, while genetic risk score for BMI is more consistently associated with worse labor market outcomes, the genetic risk score for WHR is also influential for certain important outcomes.

\footnotetext{
${ }^{14}$ Heid et al. (2010) find that the loci and processes associated with body fat distribution (i.e. WHR) are largely distinct from those that influence BMI; the loci identified with WHR in their study "display no overlap with those shown to be associated with BMI..." (p. 954).
} 


\section{Discussion}

There is a large literature on the economic consequences of obesity. Much of the evidence about causal effects is based on IV models in which the instrument for respondent weight is the weight of a biological relative. This paper contributes to the literature by using a different instrument: a genetic risk score for obesity that is based on the genetics literature and was suggested in a recent study as an example of a powerful and valid application of genes as IVs (von Hinke Kessler Scholder et al., 2016).

An additional advantage is that, to the best of our knowledge, this is the first study of weight and labor market outcomes in which both the outcomes and the weight variables are free of reporting error; i.e. the data include measured weight and height and administrative records on earnings, employment, and social income transfers. This implies that the estimates are relatively free of the problems of coefficient bias and inflated standard errors that result from error in the dependent and independent variables (Bound et al., 2001; Cawley et al., 2015; Courtemanche et al., 2015).

The estimates of our IV model confirm those of the previous literature that used the weight of a biological relative as an instrument: weight lowers wages and the probability of employment. Specifically, our IV estimates indicate that an additional unit of BMI lowers wages by $6.6 \%$ and reduces the share of years employed by $1.7 \%$. We also examine novel outcomes that relate to the negative externalities associated with excess weight; we find that an additional unit of BMI increases the probability of receiving social income transfers by 2.9 percentage points $(3.5 \%)$ and raises the amount of such social income transfers by $24.8 \%$.

Reduced form models that regress outcomes directly on the genetic risk score are also consistent with the hypothesis that additional weight worsens labor market 
outcomes; raising the genetic risk score by one (meaning that an individual has one additional allele that raises their risk of weight gain) is associated with lower earnings, a lower probability of employment, a higher probability of receiving social income transfers, and a higher amount of social income transfers received.

These findings are robust to some but not all permutations of the sample and model. The IV results are robust to controlling for genetic risk of obesity-related comorbidities such as high blood pressure, total cholesterol, and triglycerides. They are also robust to replacing BMI with obesity $(\mathrm{BMI}>=30)$ or weight in $\mathrm{kg}$ (controlling for height).

However, we caution that the sample is small $(\mathrm{N}=2,062)$, and thus when we estimate models separately by wave only one of the IV coefficients is statistically significant (although other coefficients are not significantly different from the coefficients from the overall model). The same is generally true when we estimate models separately by sex, although the IV model indicates that BMI raises the probability of receiving any social income transfers by women, and raises the amount of social income transfers received by men. Adding controls for cognitive ability reduces the size of the sample, and the IV coefficients are not statistically significant.

The evidence that weight worsens labor market outcomes is consistent with the previous literature that relied on other identification strategies. Using the weight of a biological relative as an instrument for respondent weight, Cawley (2004) found that the impact of weight on wages in the U.S. varied by race and gender. The greatest impact was found for white females, among whom an additional 10 pounds lowered wages by $2.8 \%$. Using the same identification strategy and data from nine countries in Europe, Brunello and D'Hombres (2007) found that a 10\% increase in BMI reduced the wages of females by $1.86 \%$ and those of males by $3.27 \%$ for the nine nations 
pooled. One of the nine nations represented in their data is Finland; they estimate that an additional unit of BMI reduces wages among women by $3.6 \%$ (which is statistically significant at the $10 \%$ level) and reduces wages among men by $1.2 \%$ (which is not statistically significant). Our estimates for Finnish men and women pooled indicate that a unit of BMI reduces wages by $6.6 \%$; the results estimated separately by sex are not statistically significant but the point estimates are larger for women $(10.5 \%)$ than men $(4.8 \%)$, although the difference by sex is not statistically significant.

Our results can also be compared to the previous research on the effect of weight on employment. Lindeboom et al. (2010) use the weight of a biological relative as an instrument and estimate the impact of weight on the probability of employment in the Great Britain; they cannot reject the null hypothesis of no effect. A recent study of the impact of weight on employment (Reichert, 2015) used a novel identification strategy: random assignment to a weight loss intervention that offered monetary rewards for weight loss, as opposed to assignment to a control group. The IV estimates suggest that a 1 percentage point reduction in BMI raises the probability of employment for women by 2.1 percentage points $(2.8 \%)$ but has no impact on the employment probability of men. A limitation is the small sample size $(\mathrm{N}=680)$ and uncertain generalizability (subjects were all obese and drawn from four medical rehabilitation clinics in Germany).

A recent study by some of the same authors as this study examined the impact of birth weight (instrumented using the genetic risk score for birth weight) on adult earnings (Pehkonen et al., 2015). The authors could not reject the null hypothesis of no effect; the IV estimates were large, but imprecise. 
This paper also includes the first test for a causal effect of waist-to-hip ratio on labor market outcomes. Past studies estimating the impact of weight on labor market outcomes primarily use as their measure of weight BMI or clinical classifications based on BMI. However, BMI is a limited measure of fatness in that it does not actually measure fat; it does not distinguish between fat mass and lean mass (see Burkhauser and Cawley, 2008). WHR, in contrast, is a measure of central adiposity or fatness and may be a better measure of how excess weight affects health or appearance. The IV models suggest that a higher WHR increases the amount of social income transfers; however, the genetic risk score for WHR was a relatively weak instrument. Reduced form models indicate that not only the genetic risk score for BMI, but also the genetic risk score for WHR, are associated with worse labor market outcomes. This confirms that BMI is a limited measure of fatness, and that other measures of fatness may add to the explanatory power of economic models and offer additional insights.

If, as many of these studies suggest, weight worsens labor market outcomes, an important question is why. One mechanism seems to be discrimination on the basis of appearance. Rooth (2009) conducted an audit study, sending matched resumes to job openings in Sweden, which were accompanied by photos of the fictitious applicants, the apparent weight of whom was manipulated by computer photo editing software. The apparently obese applicant was significantly less likely to be contacted for a job interview than their lighter equivalent; this disadvantage equaled 8 percentage points for women and 6 percentage points for men. Given that the resumes of these pairs were constructed to be as similar as possible, this suggests that employer hiring decisions are influenced by applicants' (apparent) weight. Other evidence is consistent with bias in pay; Gregory and Ruhm (2011) estimate IV models 
of weight on wages, using the weight of a biological relative as an instrument, and find for U.S. data that weight begins reducing wages for women at a low level of BMI (roughly 23); they interpret this as evidence that weight reduces wages not because of impaired health or lower productivity but because of employers' preferences for a slender appearance.

This is not to say that none of the impact of weight on labor market outcomes operates through health and productivity. Excess fat raises the risk of Type II diabetes, heart attack, stroke, and cancer (Hu, 2008). Morbidly obese patients who undergo bariatric surgery report after the ensuing weight loss that they are able to get more work done, do higher quality work, and make fewer mistakes (Sockalingam et al., 2015). Thus, both discrimination and health impacts are likely explanations for why weight worsens labor market outcomes.

Our findings have several policy implications. To the extent that individuals face discrimination in the labor market on the basis of their weight, policymakers may wish to consider including obesity as a protected class in anti-discrimination laws. To the extent that weight worsens health, which in turn worsens labor market outcomes, this implies that the cost-effectiveness of obesity prevention and treatment programs should take into account the labor market gains that can result from averting and reducing obesity.

We recognize a variety of limitations to the paper. It is always important to note when using the method of IV that important assumptions regarding the validity of the instruments are not testable. Although the genetics literature did not find evidence of pleiotropy - i.e. the SNPs that are used in the genetic risk score for BMI were generally not found to be linked to non-obesity-related outcomes - the failure to reject the null hypothesis of no effect is not the same as proving the null. We 
acknowledge that the exact function and mechanisms of these SNPs are not known with certainty. Although the instrument we use was offered in a recent study as an example of a powerful and valid application of genes as IVs (von Hinke Kessler Scholder et al., 2016), that study also pointed out the need for caution regarding the assumption of instrument validity.

The Local Average Treatment Effect (LATE) that we measure concerns the impact of genetic variation in weight; it is possible that variation due to other sources could have a different impact on labor market outcomes. Moreover, our IVs measure only the genetic variation due to the 32 SNPs identified by Speliotes et al. (2010), which affect weight through regulators of appetite or energy balance, or insulin secretion or response. It is possible that genetic variation in weight that operates through other mechanisms (e.g. resting metabolic rate, or propensity to add muscle mass) could also exhibit a different relationship with labor market outcomes.

Our data are from Finland, a relatively small nation, which may raise some issues of generalizability, but it is a highly economically developed country that is a member of the European Union and shares many labor market characteristics with the rest of Western Europe. Another limitation of this paper is its modest sample size, which limits our ability to estimate models separately by survey wave or by sex. Despite these limitations, the strengths of the data, such as genetic information, measured weight and height, and administrative data on wages, employment, and social income transfers, make it uniquely well-suited to answer this research question. 


\section{Acknowledgements}

The Young Finns Study has been financially supported by the Academy of Finland: grants 134309 (Eye), 126925, 121584, 124282, 129378 (Salve), 117787 (Gendi), and 41071 (Skidi), the Social Insurance Institution of Finland, Kuopio, Tampere and Turku University Hospital Medical Funds (grant 9N035 and X51001), Juho Vainio Foundation, Paavo Nurmi Foundation, Finnish Foundation of Cardiovascular Research and Finnish Cultural Foundation, Tampere Tuberculosis Foundation and Emil Aaltonen Foundation. The use of linked data is supported by the Palkansaaja Foundation. Two of the authors acknowledge the financial support from theYrjö Jahnsson foundation (grants 6646 and 6664). We thank Jani-Petri Laamanen for helpful discussant comments. Cawley thanks the Robert Wood Johnson Foundation for an Investigator Award in Health Policy Research. We thank Barton Willage for research assistance. 


\section{Works Cited}

Akee, R., Simeonova, E., Copeland, W., Angold, A., \& Costello, E.J. (2013). Young adult obesity and household income: effects of unconditional cash transfers. American Economic Journal: Applied economics, 5, 1-28.

Averett, S.L. (2011). Labor market consequences: employment, wages, disability, and absenteeism. In: Cawley, J. (Ed.): The Oxford Handbook of the Social Science of Obesity. New York: Oxford University Press.

Averett, S.L. (2014). Obesity and labor market outcomes. IZA World of Labor, 32. doi: 10.15185/izawol.32Averett, S.L., and Stifel, D.C. (2010). Race and gender differences in the cognitive effects of childhood overweight. Applied Economics Letters, 17, 1673-1679.

Barsh, G.S., Farooqi, I.S., and O'Rahilly, S. (2000). Genetics of body-weight regulation. Nature, 404, 644-651.

Bound, J., Brown, C., Mathiowetz, N., (2001). Measurement error in survey data. In: Leamer, Heckman J. (Ed.), Handbook of Econometrics, vol. 5. SpringerVerlag, New York, NY, pp. 3705-3843.

Brunello, G., and d'Hombres, B. (2007). Does body weight affect wages? Evidence from Europe. Economics and Human Biology, 5, 1-19.

Burkhauser, R.V., and Cawley, J. (2008). Beyond BMI: the value of more accurate measures of fatness and obesity in social science research. Journal of Health Economics, 27, 519-529.

Cawley, J. (2004). The impact of obesity on wages. Journal of Human Resources, 39, $451-474$.

Cawley, J. (2015). An economy of scales: a selective review of obesity's economic causes, consequences, and solutions. Journal of Health Economics, 43, 244 268.

Cawley, J., Han, E., and Norton, E.C. (2011). The validity of genes related to neurotransmitters as instrumental variables. Health Economics, 20, 884-888.

Cawley, J., Maclean, J.C., Hammer, M., and Wintfeld, N. (2015). Reporting error in weight and its implications for estimates of the economic consequences of obesity. Economics and Human Biology, 19, 27-44.

Courtemanche, C., Pinkston, J.C., and Stewart, J. (2015). Adjusting body mass for measurement error with invalid validation data. Economics and Human Biology, 19, 275-293.

Dahl, M., DeLeire, T., and Schwabish, J.A. (2011). Estimates of year-to-year volatility in earnings and in household incomes from administrative, survey, and matched data. Journal of Human Resources, 46, 750-774.

Davey Smith, G. (2011). Random allocation in observational data: how small but robust effects could facilitate hypothesis-free causal inference. Epidemiology, 22, 460-463; discussion 467-468.

De Luca, C.R., Wood, S.J., Anderson, V., Buchanan, J.A., Proffitt, T.M., Mahony, K., and Pantelis, C. (2003). Normative data from the CANTAB. I: development of executive function over the lifespan. Journal of Clinical and Experimental Neuropsychology, 25, 242-254.

Gregory, C.A., and Ruhm, C.J. (2011). Where does the wage penalty bite? In Grossman, M. and Mocan, N.H. (Eds.): Economic Aspects of Obesity. Chicago: University of Chicago Press.

Heid, I.M., Jackson, A.U., Randall, J.C., Winkler, T.W., Qi, L., Steinthorsdottir, V., ... and Yang, J. (2010). Meta-analysis identifies 13 new loci associated with 
waist-hip ratio and reveals sexual dimorphism in the genetic basis of fat distribution. Nature Genetics, 42, 949-960.

Hu, F.B. (2008). Obesity Epidemiology. New York: Oxford University Press.

International Consortium for Blood Pressure Genome-Wide Association Studies (2011). Genetic variants in novel pathways influence blood pressure and cardiovascular disease risk. Nature, 478, 103-109.

Johansson, E., Böckerman, P., Kiiskinen, U., and Heliövaara, M. (2009). Obesity and labour market success in Finland: the difference between having a high BMI and being fat. Economics and Human Biology, 7, 36-45.

Kaplowitz, P.B. (2008). Link between body fat and the timing of puberty. Pediatrics, 121(Suppl 3), S208-S217.

Kline, B., and Tobias, J.L. (2008). The wages of BMI: Bayesian analysis of a skewed treatment-response model with nonparametric endogeneity. Journal of Applied Econometrics, 23, 767-793.

Lindeboom, M., Lundborg, P., and van der Klaauw, B. (2010). Assessing the impact of obesity on labor market outcomes. Economics and Human Biology, 8, 309319.

Locke, A.E., Kahali, B., Berndt, S.I., Justice, A.E., Pers, T.H., Day, F.R., ... \& Kristiansson, K. (2015). Genetic studies of body mass index yield new insights for obesity biology. Nature, 518, 197-206.

McClellan, M., McNeil, B.J., and Newhouse, J.P. (1994). Does more intensive treatment of acute myocardial infarction in the elderly reduce mortality? Analysis using instrumental variables. Journal of the American Medical Association, 272, 859-866.

Mincer, J. (1974). Schooling, Experience, and Earnings. New York: National Bureau of Economic Research.

NCD Risk Factor Collaboration. (2016). Trends in adult body-mass index in 200 countries from 1975 to 2014: a pooled analysis of 1698 population-based measurement studies with $19 \cdot 2$ million participants. The Lancet, 387, 13771396.

Ng, M., Fleming, T., Robinson, M., Thomson, B., Graetz, N., Margono, C., ... \& Abraham, J.P. (2014). Global, regional, and national prevalence of overweight and obesity in children and adults during 1980-2013: a systematic analysis for the Global Burden of Disease Study 2013. The Lancet, 384, 766-781.

Norton, E.C., and Han, E. (2008). Genetic information, obesity and labor market outcomes. Health Economics, 17, 1089-1104.

OECD (2014). Obesity Update. Paris: OECD Publishing. http://www.oecd.org/els/health-systems/Obesity-Update-2014.pdf (accessed January 26, 2016).

OECD (2015). Education at a Glance 2015. Paris: OECD Publishing.

Palmer, T.M., Lawlor, D.A., Harbord, R.M., Sheehan, N.A., Tobias, J.H., Timpson, N.J., ... \& Sterne, J.A. (2012). Using multiple genetic variants as instrumental variables for modifiable risk factors. Statistical Methods in Medical Research, 21, 223-242.

Pazhoohi, F., and Liddle, J.R. (2012). Identifying feminine and masculine ranges for Waist-to-Hip ratio. Journal of Social, Evolutionary, and Cultural Psychology, 6, 227-232.

Pehkonen, J., Viinikainen, J., Böckerman, P., Lehtimäki, T., Rovio, S., and Raitakari, O. (2016). Early origins of adult earnings: evidence using genetic instrumental variables. Unpublished manuscript. 
Pietiläinen, K.H., Kaprio, J., Rissanen, A., Winter, T., Rimpelä, A., Viken, R.J., and Rose, R.J. (1999). Distribution and heritability of BMI in Finnish adolescents aged $16 \mathrm{y}$ and $17 \mathrm{y}$ : a study of 4884 twins and 2509 singletons. International Journal of Obesity \& Related Metabolic Disorders, 23, 107-115.

Puhl, R.M. (2011). Bias, stigma, and discrimination. In: Cawley, J. (Ed.): The Oxford Handbook of the Social Science of Obesity. New York: Oxford University Press.

Raitakari, O.T., Juonala, M., Rönnemaa, T., Keltikangas-Järvinen, L., Räsänen, L., Pietikäinen, M., ... \& Viikari, J.S. (2008). Cohort profile: the cardiovascular risk in Young Finns Study. International Journal of Epidemiology, 37, 12201226.

Reichert, A.R. (2015). Obesity, weight loss, and employment prospects: evidence from a randomized trial. Journal of Human Resources, 50, 759-810.

Ridder, G., and Moffitt, R. (2007). The econometrics of data combination. In Heckman, J.J., and Leamer, E.E. (Eds.): Handbook of Econometrics, Volume 6. Amsterdam: Elsevier.

Robbins, T.W., James, M., Owen, A.M., Sahakian, B.J., McInnes, L., and Rabbitt, P. (1994). Cambridge Neuropsychological Test Automated Battery (CANTAB): a factor analytic study of a large sample of normal elderly volunteers. Dementia (Basel, Switzerland), 5, 266-281.

Rooth, D.-O. (2009). Obesity, attractiveness, and differential treatment in hiring: a field experiment. Journal of Human Resources, 44, 710-735.

Sabia, J.J. (2007). The effect of body weight on adolescent academic performance. Southern Economic Journal, 73, 871-900.

Sarlio-Lähteenkorva, S., Silventoinen, K., and Lahelma, E. (2004). Relative weight and income at different levels of socioeconomic status. American Journal of Public Health, 94, 468-472.

Schmeiser, M.D. (2009). Expanding wallets and waistlines: the impact of family income on the BMI of women and men eligible for the earned income tax credit. Health Economics, 18, 1277-1294.

Singh, D. (1993). Adaptive significance of female physical attractiveness: role of waist-to-hip ratio. Journal of Personality and Social Psychology, 65, 293-307.

Sockalingam, S., Wnuk, S., Kantarovich, K., Meaney, C., Okrainec, A., Hawa, R., and Cassin, S. (2015). Employment outcomes one year after bariatric surgery: the role of patient and psychosocial factors. Obesity Surgery, 25, 514-522.

Speliotes, E.K., Willer, C.J., Berndt, S.I., Monda, K.L., Thorleifsson, G., Jackson, A.U., ... and Hoesel, V. (2010). Association analyses of 249,796 individuals reveal 18 new loci associated with body mass index. Nature Genetics, 42, 937-948.

Staiger, D., and Stock, J.H. (1997). Instrumental variables regression with weak instruments. Econometrica, 65, 447-486.

Teslovich, T.M., Musunuru, K., Smith, A.V., Edmondson, A.C., Stylianou, I.M., Koseki, M., ... \& Willemsen, G. (2010). Biological, clinical and population relevance of 95 loci for blood lipids. Nature, 466, 707-713.

Tyrrell, J., Jones, S.E., Beaumont, R., Astley, C.M., Lovell, R., Yaghootkar, H., ... \& Wood, A.R. (2016). Height, body mass index, and socioeconomic status: Mendelian randomisation study in UK Biobank. British Medical Journal, 352, i582.

Von Hinke Kessler Scholder, S., Smith, G.D., Lawlor, D.A., Propper, C., and Windmeijer, F. (2012). The effect of fat mass on educational attainment: 
examining the sensitivity to different identification strategies. Economics and Human Biology, 10, 405-418.

Von Hinke Kessler Scholder, S., Smith, G.D., Lawlor, D.A., Propper, C., and Windmeijer, F. (2016). Genetic markers as instrumental variables. Journal of Health Economics, 45, 131-148.

Wang, Y. (2002). Is obesity associated with early sexual maturation? A comparison of the association in American boys versus girls. Pediatrics, 110, 903-910. 
Table 1. The effect of BMI on average labor market outcomes, 2001-2012

\begin{tabular}{|c|c|c|}
\hline Panel A: Log of Average Earnings, 2001-2012 & OLS & IV \\
\hline BMI & $\begin{array}{l}-0.007 \\
(0.005)\end{array}$ & $\begin{array}{l}-0.066^{*} \\
(0.036)\end{array}$ \\
\hline F-statistics & $\ldots$ & 36.59 \\
\hline Mean outcome & 9.863 & 9.863 \\
\hline $\mathrm{N}$ & 2038 & 2038 \\
\hline Panel B: Share of Years Employed, 2001-2012 & OLS & IV \\
\hline BMI & $\begin{array}{l}-0.002 \\
(0.001)\end{array}$ & $\begin{aligned}-0.017^{*} \\
(0.009)\end{aligned}$ \\
\hline F-statistics & .. & 39.94 \\
\hline Mean outcome & 0.857 & 0.857 \\
\hline $\mathrm{N}$ & 2062 & 2062 \\
\hline $\begin{array}{l}\text { Panel C: Indicator for Social Income Transfers, } \\
\text { 2001-2012 }\end{array}$ & OLS & IV \\
\hline BMI & $\begin{array}{l}-0.001 \\
(0.002)\end{array}$ & $\begin{array}{l}0.029 * \\
(0.016)\end{array}$ \\
\hline F-statistics & .. & 36.59 \\
\hline Mean outcome & 0.821 & 0.821 \\
\hline $\mathrm{N}$ & 2038 & 2038 \\
\hline $\begin{array}{l}\text { Panel D: Log of Average Social Income Transfers, } \\
\text { 2001-2012 }\end{array}$ & OLS & IV \\
\hline BMI & $\begin{array}{l}-0.012 \\
(0.015)\end{array}$ & $\begin{array}{l}0.248 * * \\
(0.119)\end{array}$ \\
\hline F-statistics & .. & 36.59 \\
\hline Mean outcome & 5.603 & 5.603 \\
\hline $\mathrm{N}$ & 2038 & 2038 \\
\hline
\end{tabular}

Notes: Earnings are measured as the log of average earnings over the period 2001-2012. Employment is measured as the average share of employment years over the period 2001-2012. Indicator for social income transfers equals one for those who have received social security transfers at least once during 2001-2012. Social income transfers are measured as the log of average transfers over the period 20012012. The mean values for the dependent variables are reported. BMI is measured in 2001 . All models include controls for the birth month and birth year effects. Gender, height (2001), and parental education (1980) are also controlled for in all models. The instrument used in the IV models is the BMI risk score, based on genetic markers. Angrist-Pischke multivariate F-tests of excluded instrument are reported for the IV models. Heteroscedasticity-robust standard errors are reported in parentheses: *statistically significant at the 0.10 level; **at the 0.05 level; *** at the 0.01 level. 
Table 2. Reduced form IV estimates

\begin{tabular}{|l|c|}
\hline Panel A & BMI risk score \\
\hline $\begin{array}{l}\text { Log of Average Earnings, 2001- } \\
2012\end{array}$ & $-0.011^{*}$ \\
$(0.006)$
\end{tabular}

Notes: Earnings are measured as the log of average earnings over the period 2001-2012. Employment is measured as the average share of employment years over the period 2001-2012. Indicator for social income transfers equals one for those who have received social security transfers at least once during 2001-2012. Social income transfers are measured as the log of average transfers over the period 20012012. The mean values for the dependent variables are reported. All models include controls for the birth month and birth year effects. Gender, height, and parental education (1980) are also controlled for in all models. Heteroscedasticity-robust standard errors are reported in parentheses: *statistically significant at the 0.10 level; **at the 0.05 level. 
Table 3. The effect of BMI on contemporaneous labor market outcomes

\begin{tabular}{|c|c|c|c|c|c|c|}
\hline & \multicolumn{2}{|c|}{2001} & \multicolumn{2}{|c|}{2007} & \multicolumn{2}{|c|}{2011} \\
\hline & $\overline{\text { OLS }}$ & IV & OLS & IV & OLS & IV \\
\hline \multicolumn{7}{|c|}{ Panel A: Log of Earnings } \\
\hline BMI & $\begin{array}{c}-0.015 \\
(0.015)\end{array}$ & $\begin{array}{c}-0.179^{*} \\
(0.104)\end{array}$ & $\begin{array}{l}-0.004 \\
(0.014)\end{array}$ & $\begin{array}{c}0.047 \\
(0.106)\end{array}$ & $\begin{array}{c}-0.005 \\
(0.012)\end{array}$ & $\begin{array}{l}-0.007 \\
(0.086)\end{array}$ \\
\hline F-statistics & .. & 36.59 & .. & 32.09 & .. & 39.17 \\
\hline $\begin{array}{l}\text { Mean } \\
\text { outcome }\end{array}$ & \multicolumn{2}{|c|}{8.912} & \multicolumn{2}{|c|}{9.433} & \multicolumn{2}{|c|}{9.629} \\
\hline $\mathrm{N}$ & \multicolumn{2}{|c|}{2038} & \multicolumn{2}{|c|}{1659} & \multicolumn{2}{|c|}{1729} \\
\hline \multicolumn{7}{|c|}{ Panel B: Indicator for Being Employed } \\
\hline BMI & $\begin{array}{c}-0.002 \\
(0.002)\end{array}$ & $\begin{array}{l}-0.021 \\
(0.015)\end{array}$ & $\begin{array}{l}-0.002 \\
(0.002)\end{array}$ & $\begin{array}{c}0.008 \\
(0.013)\end{array}$ & $\begin{array}{c}-0.002 \\
(0.002)\end{array}$ & $\begin{array}{c}0.001 \\
(0.011)\end{array}$ \\
\hline F-statistics & .. & 39.94 & .. & 34.07 & ... & 40.80 \\
\hline $\begin{array}{l}\text { Mean } \\
\text { outcome }\end{array}$ & \multicolumn{2}{|c|}{0.807} & \multicolumn{2}{|c|}{0.887} & \multicolumn{2}{|c|}{0.906} \\
\hline $\mathrm{N}$ & \multicolumn{2}{|c|}{2062} & \multicolumn{2}{|c|}{1672} & \multicolumn{2}{|c|}{1742} \\
\hline \multicolumn{7}{|c|}{ Panel C: Indicator for Social Income Transfers } \\
\hline BMI & $\begin{array}{c}0.002 \\
(0.003)\end{array}$ & $\begin{array}{c}0.005 \\
(0.019)\end{array}$ & $\begin{array}{c}0.002 \\
(0.003)\end{array}$ & $\begin{array}{l}-0.019 \\
(0.019)\end{array}$ & $\begin{array}{c}0.000 \\
(0.002)\end{array}$ & $\begin{array}{c}0.015 \\
(0.017)\end{array}$ \\
\hline F-statistics & & 36.59 & .. & 32.09 & .. & 39.17 \\
\hline $\begin{array}{l}\text { Mean } \\
\text { outcome }\end{array}$ & \multicolumn{2}{|c|}{0.367} & \multicolumn{2}{|c|}{0.334} & \multicolumn{2}{|c|}{0.291} \\
\hline $\mathrm{N}$ & \multicolumn{2}{|c|}{2038} & \multicolumn{2}{|c|}{1659} & \multicolumn{2}{|c|}{1729} \\
\hline \multicolumn{7}{|c|}{ Panel D: Log of Social Income Transfers } \\
\hline BMI & $\begin{array}{c}0.020 \\
(0.020)\end{array}$ & $\begin{array}{c}0.107 \\
(0.152)\end{array}$ & $\begin{array}{c}0.022 \\
(0.021)\end{array}$ & $\begin{array}{l}-0.128 \\
(0.158)\end{array}$ & $\begin{array}{l}-0.001 \\
(0.019)\end{array}$ & $\begin{array}{c}0.131 \\
(0.137)\end{array}$ \\
\hline F-statistics & .. & 36.59 & .. & 32.09 & .. & 39.17 \\
\hline $\begin{array}{l}\text { Mean } \\
\text { outcome }\end{array}$ & \multicolumn{2}{|c|}{2.822} & \multicolumn{2}{|c|}{2.548} & \multicolumn{2}{|c|}{2.168} \\
\hline $\mathrm{N}$ & \multicolumn{2}{|c|}{2038} & \multicolumn{2}{|c|}{1659} & \multicolumn{2}{|c|}{1729} \\
\hline
\end{tabular}

Notes: The outcomes and BMI are measured in 2001, 2007 and 2011. All models include controls for the birth month and birth year effects. Gender, contemporaneous height, and parental education (1980) are also controlled for in all models. The instrument used in the IV models is the BMI risk score, based on genetic markers. Angrist-Pischke multivariate F-tests of excluded instrument are reported for the IV models. Heteroscedasticity-robust standard errors are reported in parentheses: *statistically significant at the 0.10 level; **at the 0.05 level; *** at the 0.01 level. 
Table 4. The effect of BMI on average labor market outcomes, 2001-2012 with controls for other genetic markers

\begin{tabular}{|c|c|c|}
\hline $\begin{array}{l}\text { Panel A: Log of Average Earnings, 2001- } \\
2012\end{array}$ & OLS & IV \\
\hline BMI & $\begin{array}{l}-0.007 \\
(0.005)\end{array}$ & $\begin{array}{l}-0.067^{*} \\
(0.036)\end{array}$ \\
\hline F-statistics & ... & 36.78 \\
\hline Mean outcome & 9.860 & 9.860 \\
\hline $\mathrm{N}$ & 2001 & 2001 \\
\hline $\begin{array}{l}\text { Panel B: Share of Years Employed, 2001- } \\
2012\end{array}$ & OLS & IV \\
\hline BMI & $\begin{array}{l}-0.002 \\
(0.001)\end{array}$ & $\begin{array}{c}-0.015^{*} \\
(0.009)\end{array}$ \\
\hline F-statistics & .. & 40.14 \\
\hline Mean outcome & 0.857 & 0.857 \\
\hline $\mathrm{N}$ & 2024 & 2024 \\
\hline $\begin{array}{l}\text { Panel C: Indicator for Social Income } \\
\text { Transfers, 2001-2012 }\end{array}$ & OLS & IV \\
\hline BMI & $\begin{array}{l}-0.002 \\
(0.002)\end{array}$ & $\begin{array}{l}0.026^{*} \\
(0.015)\end{array}$ \\
\hline F-statistics &. & 36.78 \\
\hline Mean outcome & 0.822 & 0.822 \\
\hline $\mathrm{N}$ & 2001 & 2001 \\
\hline $\begin{array}{l}\text { Panel D: Log of Average Social Income } \\
\text { Transfers, 2001-2012 }\end{array}$ & OLS & IV \\
\hline BMI & $\begin{array}{l}-0.015 \\
(0.015)\end{array}$ & $\begin{array}{l}0.225^{*} \\
(0.117)\end{array}$ \\
\hline F-statistics & .. & 36.78 \\
\hline Mean outcome & 5.615 & 5.615 \\
\hline $\mathrm{N}$ & 2001 & 2001 \\
\hline
\end{tabular}

Notes: Earnings are measured as the log of average earnings over the period 2001-2012. Employment is measured as the average share of employment years over the period 2001-2012. Indicator for social income transfers equals one for those who have received social security transfers at least once during 2001-2012. Social income transfers are measured as the log of average transfers over the period 20012012. The mean values for the dependent variables are reported. BMI is measured in 2001. All models include controls for the birth month and birth year effects. Gender, height (2001), and parental education (1980) are also controlled for in all models. The instrument used in the IV models is the BMI risk score, based on genetic markers. Angrist-Pischke multivariate F-tests of excluded instrument are reported for the IV models. Heteroscedasticity-robust standard errors are reported in parentheses: *statistically significant at the 0.10 level; **at the 0.05 level; *** at the 0.01 level. 


\section{Appendix A1: Tests of cognitive ability}

In the latest follow-up of YFS (2011-12), cognitive function was assessed with commercially available Cambridge Neuropsychological Test Automated Battery $\left(\mathrm{CANTAB}^{\circledR}\right)$. The $\mathrm{CANTAB}^{\circledR}$ is a computerized, predominantly non-linguistic and culturally neutral test performed using a validated touch-screen computer system. The full test battery includes 25 individual tests from which, five age sensitive tests (Robbins et al. 1994; DeLuca et al. 2003) were selected for YFS. The tests measured several cognitive domains: 1) short term memory, 2) spatial working memory, 3) problem solving, 4) reaction time, 5) attention, 6) rapid visual processing, 7) visual memory, 8) episodic memory, and 9) visuospatial learning.

During cognitive testing the participants first conducted a motor screening test (MOT) measuring psychomotor speed and accuracy. In this study, the MOT test was considered as a training procedure in which the participants were introduced to the equipment used in the testing, and as a screening tool to point out any difficulties in vision, movement, comprehension or ability to follow simple instructions. Paired associates learning (PAL) test was used to assess visual and episodic memory as well as visuospatial associative learning containing aspects of both delayed response procedure and conditional learning. Spatial working memory (SWM) test was used to measure ability to retain spatial information and to manipulate items stored in the working memory, problem solving as well as the ability to conduct a self-organized search strategy. Reaction time (RTI) test assessed speed of response and movement on tasks where the stimulus was either predictable (simple location task) or unpredictable (five-choice location task). Rapid visual information (RVP) test was used to assess visual processing, recognition and sustained attention.

Each of the CANTAB ${ }^{\circledR}$ tests produced several variables. Therefore, principal component analysis was conducted to reduce the number of variables and to identify components accounting for the majority of the variation within the cognition dataset. First, principal component analysis was conducted for the complete cognitive data and the resulting first component was considered as an indicator for overall cognitive performance. Second, principal component analyses were performed separately for all individual tests (MOT, PAL, SWM, RTI, RVP). The first components resulting from these analyses were considered to represent cognitive performance related to the particular domain. After creating the overall and testwise principal components their distributions were analyzed. The component for MOT test was excluded from further analyses because it did not discriminate the subjects indicating a ceiling effect. All other components were normalized based on the rank order normalization procedure resulting in five separate variables, each with mean value of 0 and standard deviation of 1 . 


\section{Appendix Table A2: \\ Descriptive statistics}

\begin{tabular}{|c|c|c|}
\hline Variable & Mean (SD) & $\mathbf{N}$ \\
\hline Average earnings (2001-2012), euros & $24527.93(15042.27)$ & 2038 \\
\hline Share of years employed (2001-2012) & $0.857(0.245)$ & 2062 \\
\hline Indicator for social income transfers (2001-2012) & $0.821(0.384)$ & 2038 \\
\hline $\begin{array}{l}\text { Average social income transfers (2001-2012), } \\
\text { euros }\end{array}$ & $1845.67(2375.05)$ & 2038 \\
\hline Earnings (2001), euros & $18915.49(14382.31)$ & 2038 \\
\hline Earnings (2007), euros & $26270.74(19529.69)$ & 1659 \\
\hline Earnings (2011), euros & $29528.85(19952.31)$ & 1729 \\
\hline Indicator for being employed (2001) & $0.807(0.395)$ & 2062 \\
\hline Indicator for being employed (2007) & $0.887(0.317)$ & 1672 \\
\hline Indicator for being employed (2011) & $0.906(0.291)$ & 1742 \\
\hline Indicator for social income transfers (2001) & $0.367(0.482)$ & 2038 \\
\hline Indicator for social income transfers (2007) & $0.334(0.472)$ & 1659 \\
\hline Indicator for social income transfers (2011) & $0.291(0.454)$ & 1729 \\
\hline Social income transfers (2001), euros & $1584.18(3152.20)$ & 2038 \\
\hline Social income transfers (2007), euros & $1752.15(3838.53)$ & 1659 \\
\hline Social income transfers (2011), euros & $1836.76(4386.63)$ & 1729 \\
\hline BMI (2001) & $25.052(4.290)$ & 2038 \\
\hline BMI (2007) & $25.864(4.485)$ & 1659 \\
\hline BMI (2011) & $26.338(4.621)$ & 1729 \\
\hline BMI risk score & $29.144(3.358)$ & 2038 \\
\hline Height (2001) & $172.252(9.151)$ & 2038 \\
\hline Height (2007) & $172.247(9.254)$ & 1659 \\
\hline Height (2011) & $172.407(9.271)$ & 1729 \\
\hline $\mathrm{BMI}>=30(2001)$ & $0.124(0.329)$ & 2038 \\
\hline Weight (2001) & $74.686(15.854)$ & 2038 \\
\hline Waist-hip ratio (2001) & $0.841(0.082)$ & 1972 \\
\hline Waist-hip risk score & $15.202(2.358)$ & 1972 \\
\hline University education (1980), mother & $0.072(0.258)$ & 2038 \\
\hline University education (1980), father & $0.102(0.303)$ & 2038 \\
\hline Income (1980), mother (euros) & $4616.65(3503.96)$ & 2023 \\
\hline Income (1980), father (euros) & $8739.78(5775.44)$ & 1931 \\
\hline Married (2001) & $0.445(0.497)$ & 2038 \\
\hline Overall cognitive performance (2011-2012) & $0.010(0.996)$ & 1334 \\
\hline $\begin{array}{l}\text { Visual and episodic memory and visuospatial } \\
\text { associative learning }\end{array}$ & $0.013(0.989)$ & 1334 \\
\hline Reaction time & $0.021(0.996)$ & 1334 \\
\hline Rapid visual information processing & $0.042(0.985)$ & 1334 \\
\hline Spatial working memory & $0.005(0.974)$ & 1334 \\
\hline Genetic risk score for blood pressure & $30.449(3.215)$ & 2001 \\
\hline
\end{tabular}




\begin{tabular}{|l|l|l|}
\hline Genetic risk score for total cholesterol & $27.462(3.089)$ & 2001 \\
\hline Genetic risk score for triglycerides & $26.128(2.875)$ & 2001 \\
\hline
\end{tabular}

Notes: Descriptive statistics are reported for the samples that are used in the estimations. 
Appendix Table A3:

Comparison of observables by value of instrument

\begin{tabular}{|c|c|c|c|c|}
\hline & $\begin{array}{c}\text { Below } \\
\text { average BMI } \\
\text { risk score } \\
\end{array}$ & $\begin{array}{c}\text { Above } \\
\text { average BMI } \\
\text { risk score } \\
\end{array}$ & Difference & t-statistics \\
\hline & Mean (SD) & Mean (SD) & & \\
\hline $\begin{array}{l}\text { Earnings, } \\
\text { 2001-2012 (euros) }\end{array}$ & $\begin{array}{c}25237.39 \\
(15263.52) \\
\end{array}$ & $\begin{array}{c}23743.71 \\
(14762.08) \\
\end{array}$ & 1493.685 & $2.241 * *$ \\
\hline $\begin{array}{l}\text { Share of years } \\
\text { employed, 2001- } \\
2012\end{array}$ & $\begin{array}{c}0.865 \\
(0.241)\end{array}$ & $\begin{array}{c}0.848 \\
(0.249)\end{array}$ & 0.017 & 1.575 \\
\hline $\begin{array}{l}\text { Indicator for social } \\
\text { income transfers, } \\
2001-2012\end{array}$ & $\begin{array}{c}0.809 \\
(0.393)\end{array}$ & $\begin{array}{c}0.834 \\
(0.373)\end{array}$ & -0.024 & -1.434 \\
\hline $\begin{array}{l}\text { Social income } \\
\text { transfers, 2001-2012 } \\
\text { (euros) }\end{array}$ & $\begin{array}{c}1592.72 \\
(2079.09)\end{array}$ & $\begin{array}{l}1731.16 \\
(2160.78)\end{array}$ & -138.442 & -1.473 \\
\hline BMI (2001) & $\begin{array}{r}24.615 \\
(4.095) \\
\end{array}$ & $\begin{array}{l}25.535 \\
(4.449)\end{array}$ & -0.920 & $-4.840 * * *$ \\
\hline Married (2001) & $\begin{array}{c}0.445 \\
(0.497)\end{array}$ & $\begin{array}{c}0.444 \\
(0.497)\end{array}$ & 0.001 & 0.029 \\
\hline \multicolumn{5}{|l|}{$\begin{array}{l}\text { Cognitive skills } \\
(2011-2012)\end{array}$} \\
\hline $\begin{array}{l}\text { Visual and episodic } \\
\text { memory and } \\
\text { visuospatial } \\
\text { associative learning }\end{array}$ & $\begin{array}{c}0.042 \\
(0.940)\end{array}$ & $\begin{array}{l}-0.019 \\
(1.040)\end{array}$ & 0.061 & 1.114 \\
\hline Reaction time & $\begin{array}{c}0.007 \\
(1.007) \\
\end{array}$ & $\begin{array}{c}0.036 \\
(0.984) \\
\end{array}$ & -0.028 & -0.517 \\
\hline $\begin{array}{l}\text { Rapid visual } \\
\text { information } \\
\text { processing }\end{array}$ & $\begin{array}{c}0.130 \\
(0.976)\end{array}$ & $\begin{array}{l}-0.057 \\
(0.987)\end{array}$ & 0.187 & $3.481 * * *$ \\
\hline $\begin{array}{l}\text { Spatial working } \\
\text { memory }\end{array}$ & $\begin{array}{c}0.063 \\
(0.977) \\
\end{array}$ & $\begin{array}{l}-0.061 \\
(0.967)\end{array}$ & 0.124 & $2.321 * *$ \\
\hline \multicolumn{5}{|l|}{$\begin{array}{l}\text { Family background } \\
\text { (1980) }\end{array}$} \\
\hline $\begin{array}{l}\text { Income, mother } \\
\text { (euros) }\end{array}$ & $\begin{array}{c}4734.06 \\
(3634.87)\end{array}$ & $\begin{array}{c}4486.90 \\
(3350.45)\end{array}$ & 247.164 & 1.591 \\
\hline $\begin{array}{l}\text { Income, father } \\
\text { (euros) }\end{array}$ & $\begin{array}{r}8803.89 \\
(5578.61) \\
\end{array}$ & $\begin{array}{r}8668.88 \\
(5987.82) \\
\end{array}$ & 135.016 & 0.511 \\
\hline $\begin{array}{l}\text { University education, } \\
\text { mother }\end{array}$ & $\begin{array}{c}0.071 \\
(0.257)\end{array}$ & $\begin{array}{c}0.072 \\
(0.259)\end{array}$ & -0.001 & -0.112 \\
\hline $\begin{array}{l}\text { University education, } \\
\text { father }\end{array}$ & $\begin{array}{c}0.100 \\
(0.300)\end{array}$ & $\begin{array}{c}0.104 \\
(0.306)\end{array}$ & -0.004 & -0.323 \\
\hline
\end{tabular}


Appendix Table A4:

The effect of BMI on average labor market outcomes, 2001-2012 with controls for cognitive ability

\begin{tabular}{|c|c|c|}
\hline $\begin{array}{l}\text { Panel A: Log of Average Earnings, 2001- } \\
2012\end{array}$ & OLS & IV \\
\hline BMI & $\begin{array}{l}-0.006 \\
(0.005)\end{array}$ & $\begin{array}{l}-0.020 \\
(0.029) \\
\end{array}$ \\
\hline F-statistics & 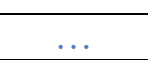 & 34.61 \\
\hline Mean outcome & 9.956 & 9.956 \\
\hline $\mathrm{N}$ & 1334 & 1334 \\
\hline $\begin{array}{l}\text { Panel B: Share of Years Employed, 2001- } \\
2012\end{array}$ & OLS & IV \\
\hline BMI & $\begin{array}{l}-0.000 \\
(0.001)\end{array}$ & $\begin{array}{l}-0.006 \\
(0.008)\end{array}$ \\
\hline F-statistics & .. & 34.74 \\
\hline Mean outcome & 0.886 & 0.886 \\
\hline $\mathrm{N}$ & 1339 & 1339 \\
\hline $\begin{array}{l}\text { Panel C: Indicator for Social Income } \\
\text { Transfers, 2001-2012 }\end{array}$ & $\overline{\text { OLS }}$ & IV \\
\hline BMI & $\begin{array}{l}-0.003 \\
(0.003)\end{array}$ & $\begin{array}{c}0.024 \\
(0.016)\end{array}$ \\
\hline F-statistics & .. & 34.61 \\
\hline Mean outcome & 0.813 & 0.813 \\
\hline $\mathrm{N}$ & 1334 & 1334 \\
\hline $\begin{array}{l}\text { Panel D: Log of Average Social Income } \\
\text { Transfers, 2001-2012 }\end{array}$ & OLS & IV \\
\hline BMI & $\begin{array}{l}-0.013 \\
(0.019) \\
\end{array}$ & $\begin{array}{l}0.209^{*} \\
(0.122) \\
\end{array}$ \\
\hline F-statistics & .. & 34.61 \\
\hline Mean outcome & 5.477 & 5.477 \\
\hline $\mathrm{N}$ & 1334 & 1334 \\
\hline
\end{tabular}

Notes: Earnings are measured as the log of average earnings over the period 2001-2012. Employment is measured as the average share of employment years over the period 2001-2012. Indicator for social income transfers equals one for those who have received social security transfers at least once during 2001-2012. Social income transfers are measured as the log of average transfers over the period 20012012. The mean values for the dependent variables are reported. BMI is measured in 2001. All models include controls for the birth month and birth year effects. Gender, height (2001), and parental education (1980) are also controlled for in all models. The instrument used in the IV models is the BMI risk score, based on genetic markers. Angrist-Pischke multivariate F-tests of excluded instrument are reported for the IV models. Heteroscedasticity-robust standard errors are reported in parentheses: *statistically significant at the 0.10 level; **at the 0.05 level; *** at the 0.01 level. 
Appendix Table A5:

The effect of BMI on average labor market outcomes 2001-2012 for men

\begin{tabular}{|c|c|c|}
\hline $\begin{array}{l}\text { Panel A: Log of Average Earnings, } \\
\underline{2001-2012}\end{array}$ & OLS & IV \\
\hline BMI & $\begin{array}{l}-0.005 \\
(0.008)\end{array}$ & $\begin{array}{l}-0.048 \\
(0.037)\end{array}$ \\
\hline F-statistics & .. & 29.07 \\
\hline Mean outcome & 10.082 & 10.082 \\
\hline $\mathrm{N}$ & 929 & 929 \\
\hline Panel B: Share of Years Employed, & OLS & IV \\
\hline BMI & $\begin{array}{l}-0.001 \\
(0.002)\end{array}$ & $\begin{array}{r}-0.017 \\
(0.011)\end{array}$ \\
\hline F-statistics &. & 29.60 \\
\hline Mean outcome & 0.889 & 0.889 \\
\hline $\mathrm{N}$ & 937 & 937 \\
\hline $\begin{array}{l}\text { Panel C: Indicator for Social } \\
\text { Income Transfers, 2001-2012 }\end{array}$ & OLS & IV \\
\hline BMI & $\begin{array}{l}-0.004 \\
(0.003)\end{array}$ & $\begin{array}{c}0.021 \\
(0.020)\end{array}$ \\
\hline F-statistics & .. & 29.07 \\
\hline Mean outcome & 0.763 & 0.763 \\
\hline $\mathrm{N}$ & 929 & 929 \\
\hline $\begin{array}{l}\text { Panel D: Log of Average Social } \\
\text { Income Transfers, 2001-2012 }\end{array}$ & OLS & IV \\
\hline BMI & $\begin{array}{l}-0.029 \\
(0.024)\end{array}$ & $\begin{array}{l}0.266^{*} \\
(0.148)\end{array}$ \\
\hline F-statistics &.. & 29.07 \\
\hline Mean outcome & 4.765 & 4.765 \\
\hline $\mathrm{N}$ & 929 & 929 \\
\hline
\end{tabular}

Notes: Earnings are measured as the log of average earnings over the period 2001-2012. Employment is measured as the average share of employment years over the period 2001-2012. Indicator for social income transfers equals one for those who have received social security transfers at least once during 2001-2012. Social income transfers are measured as the log of average transfers over the period 20012012. The mean values for the dependent variables are reported. BMI is measured in 2001. All models include controls for the birth month and birth year effects. Height (2001), and parental education (1980) are also controlled for in all models. The instrument used in the IV models is the BMI risk score, based on genetic markers. Angrist-Pischke multivariate F-tests of excluded instrument are reported for the IV models. Heteroscedasticity-robust standard errors are reported in parentheses: *statistically significant at the 0.10 level; **at the 0.05 level; *** at the 0.01 level. 
Appendix Table A6:

The effect of BMI on average labor market outcomes 2001-2012 for women

\begin{tabular}{|c|c|c|}
\hline $\begin{array}{l}\text { Panel A: Log of Average Earnings, } \\
\underline{2001-2012}\end{array}$ & OLS & IV \\
\hline BMI & $\begin{array}{l}-0.008 \\
(0.007)\end{array}$ & $\begin{array}{l}-0.105 \\
(0.077)\end{array}$ \\
\hline F-statistics & .. & 9.08 \\
\hline Mean outcome & 9.679 & 9.679 \\
\hline $\mathrm{N}$ & 1109 & 1109 \\
\hline Panel B: Share of Years Employed, & OLS & IV \\
\hline BMI & $\begin{array}{l}-0.002 \\
(0.002)\end{array}$ & $\begin{array}{r}-0.019 \\
(0.017)\end{array}$ \\
\hline F-statistics & .. & 11.61 \\
\hline Mean outcome & 0.831 & 0.831 \\
\hline $\mathrm{N}$ & 1125 & 1125 \\
\hline $\begin{array}{l}\text { Panel C: Indicator for Social } \\
\text { Income Transfers, 2001-2012 }\end{array}$ & OLS & IV \\
\hline BMI & $\begin{array}{c}0.001 \\
(0.002)\end{array}$ & $\begin{array}{l}0.052^{*} \\
(0.030)\end{array}$ \\
\hline F-statistics & .. & 9.08 \\
\hline Mean outcome & 0.869 & 0.869 \\
\hline $\mathrm{N}$ & 1109 & 1109 \\
\hline $\begin{array}{l}\text { Panel D: Log of Average Social } \\
\text { Income Transfers, 2001-2012 }\end{array}$ & OLS & IV \\
\hline BMI & $\begin{array}{c}0.004 \\
(0.019) \\
\end{array}$ & $\begin{array}{c}0.300 \\
(0.224)\end{array}$ \\
\hline F-statistics & .. & 9.08 \\
\hline Mean outcome & 6.305 & 6.305 \\
\hline $\mathrm{N}$ & 1109 & 1109 \\
\hline
\end{tabular}

Notes: Earnings are measured as the log of average earnings over the period 2001-2012. Employment is measured as the average share of employment years over the period 2001-2012. Indicator for social income transfers equals one for those who have received social security transfers at least once during 2001-2012. Social income transfers are measured as the log of average transfers over the period 20012012. The mean values for the dependent variables are reported. BMI is measured in 2001. All models include controls for the birth month and birth year effects. Height (2001), and parental education (1980) are also controlled for in all models. The instrument used in the IV models is the BMI risk score, based on genetic markers. Angrist-Pischke multivariate F-tests of excluded instrument are reported for the IV models. Heteroscedasticity-robust standard errors are reported in parentheses: *statistically significant at the 0.10 level; **at the 0.05 level; *** at the 0.01 level. 
Appendix Table A7:

The effect of obesity (BMI $\geq 30$ ) on average labor market outcomes 2001-2012

\begin{tabular}{|c|c|c|}
\hline $\begin{array}{l}\text { Panel A: Log of Average Earnings, } \\
\underline{2001-2012}\end{array}$ & OLS & IV \\
\hline Obesity (BMI $\geq 30$ ) & $\begin{array}{l}-0.135 * * \\
(0.068)\end{array}$ & $\begin{array}{l}-1.028^{*} \\
(0.563)\end{array}$ \\
\hline F-statistics & .. & 24.95 \\
\hline Mean outcome & 9.863 & 9.863 \\
\hline $\mathrm{N}$ & 2038 & 2038 \\
\hline Panel B: Share of Years Employed, & OLS & IV \\
\hline Obesity (BMI $\geq 30)$ & $\begin{array}{l}-0.032 * \\
(0.018)\end{array}$ & $\begin{array}{l}-0.266^{*} \\
(0.144) \\
\end{array}$ \\
\hline F-statistics & & 27.75 \\
\hline Mean outcome & 0.857 & 0.857 \\
\hline $\mathrm{N}$ & 2062 & 2062 \\
\hline $\begin{array}{l}\text { Panel C: Indicator for Social } \\
\text { Income Transfers, 2001-2012 }\end{array}$ & OLS & IV \\
\hline Obesity (BMI $\geq 30)$ & $\begin{array}{l}-0.023 \\
(0.027)\end{array}$ & $\begin{array}{l}0.457^{*} \\
(0.249)\end{array}$ \\
\hline F-statistics & .. & 24.95 \\
\hline Mean outcome & 0.821 & 0.821 \\
\hline $\mathrm{N}$ & 2038 & 2038 \\
\hline $\begin{array}{l}\text { Panel D: Log of Average Social } \\
\text { Income Transfers, 2001-2012 }\end{array}$ & OLS & IV \\
\hline Obesity $(\mathrm{BMI} \geq 30)$ & $\begin{array}{l}-0.138 \\
(0.199)\end{array}$ & $\begin{array}{c}3.867^{* *} \\
(1.914)\end{array}$ \\
\hline F-statistics & & 24.95 \\
\hline Mean outcome & 5.603 & 5.603 \\
\hline $\mathrm{N}$ & 2038 & 2038 \\
\hline
\end{tabular}

Notes: Obesity indicator equals one for whose BMI was at least 30 in 2001. Earnings are measured as the log of average earnings over the period 2001-2012. Employment is measured as the average share of employment years over the period 2001-2012. Indicator for social income transfers equals one for those who have received social security transfers at least once during 2001-2012. Social income transfers are measured as the log of average transfers over the period 2001-2012. The mean values for the dependent variables are reported. All models include controls for the birth month and birth year effects. Gender, height (2001), and parental education (1980) are also controlled for in all models. The instrument used in the IV models is the BMI risk score, based on genetic markers. Angrist-Pischke multivariate F-tests of excluded instrument are reported for the IV models. Heteroscedasticity-robust standard errors are reported in parentheses: *statistically significant at the 0.10 level; **at the 0.05 level; *** at the 0.01 level. 


\section{Appendix Table A8: \\ The effect of weight $(\mathrm{kg})$ on average labor market outcomes 2001-2012}

\begin{tabular}{|c|c|c|}
\hline $\begin{array}{l}\text { Panel A: Log of Average Earnings, } \\
\underline{2001-2012}\end{array}$ & OLS & IV \\
\hline Weight (kg) & $\begin{array}{l}-0.002 \\
(0.002)\end{array}$ & $\begin{array}{l}-0.022^{*} \\
(0.012)\end{array}$ \\
\hline F-statistics & .. & 37.80 \\
\hline Mean outcome & 9.863 & 9.863 \\
\hline $\mathrm{N}$ & 2038 & 2038 \\
\hline Panel B: Share of Years Employed, & OLS & IV \\
\hline Weight (kg) & $\begin{array}{l}-0.001 \\
(0.000)\end{array}$ & $\begin{array}{l}-0.006^{*} \\
(0.003)\end{array}$ \\
\hline F-statistics & & 41.06 \\
\hline Mean outcome & 0.857 & 0.857 \\
\hline $\mathrm{N}$ & 2062 & 2062 \\
\hline $\begin{array}{l}\text { Panel C: Indicator for Social } \\
\text { Income Transfers, 2001-2012 }\end{array}$ & OLS & IV \\
\hline Weight (kg) & $\begin{array}{l}-0.001 \\
(0.001)\end{array}$ & $\begin{array}{l}0.010^{*} \\
(0.005)\end{array}$ \\
\hline F-statistics & .. & 37.80 \\
\hline Mean outcome & 0.821 & 0.821 \\
\hline $\mathrm{N}$ & 2038 & 2038 \\
\hline $\begin{array}{l}\text { Panel D: Log of Average Social } \\
\text { Income Transfers, 2001-2012 }\end{array}$ & OLS & IV \\
\hline Weight (kg) & $\begin{array}{l}-0.004 \\
(0.005)\end{array}$ & $\begin{array}{c}0.081 * * \\
(0.039)\end{array}$ \\
\hline F-statistics & & 37.80 \\
\hline Mean outcome & 5.603 & 5.603 \\
\hline $\mathrm{N}$ & 2038 & 2038 \\
\hline
\end{tabular}

Notes: Weight $(\mathrm{kg})$ is measured in 2001. Earnings are measured as the log of average earnings over the period 2001-2012. Employment is measured as the average share of employment years over the period 2001-2012. Indicator for social income transfers equals one for those who have received social security transfers at least once during 2001-2012. Social income transfers are measured as the log of average transfers over the period 2001-2012. The mean values for the dependent variables are reported. All models include controls for the birth month and birth year effects. Gender, height (2001), and parental education (1980) are also controlled for in all models. The instrument used in the IV models is the BMI risk score, based on genetic markers. Angrist-Pischke multivariate F-tests of excluded instrument are reported for the IV models. Heteroscedasticity-robust standard errors are reported in parentheses: *statistically significant at the 0.10 level; **at the 0.05 level; *** at the 0.01 level. 
Appendix Table A9:

The effect of waist-hip ratio on average labor market outcomes 2001-2012

\begin{tabular}{|c|c|c|}
\hline Panel A: Log of Average Earnings, & OLS & IV \\
\hline Waist-hip ratio & $\begin{array}{c}-1.541 * * * \\
(0.337)\end{array}$ & $\begin{array}{l}-11.170 \\
(6.988) \\
\end{array}$ \\
\hline F-statistics & & 5.49 \\
\hline Mean outcome & 9.861 & 9.861 \\
\hline $\mathrm{N}$ & 1972 & 1972 \\
\hline $\begin{array}{l}\text { Panel B: Share of Years Employed, } \\
\text { 2001-2012 }\end{array}$ & OLS & IV \\
\hline Waist-hip ratio & $\begin{array}{c}-0.328^{* * *} \\
(0.095)\end{array}$ & $\begin{array}{l}-2.931 \\
(1.937)\end{array}$ \\
\hline F-statistics & - & 6.17 \\
\hline Mean outcome & 0.858 & 0.858 \\
\hline $\mathrm{N}$ & 1995 & 1995 \\
\hline $\begin{array}{l}\text { Panel C: Indicator for Social } \\
\text { Income Transfers, 2001-2012 }\end{array}$ & $\overline{\text { OLS }}$ & IV \\
\hline Waist-hip ratio & $\begin{array}{c}0.219 \\
(0.146) \\
\end{array}$ & $\begin{array}{c}4.221 \\
(3.176) \\
\end{array}$ \\
\hline F-statistics & .. & 5.49 \\
\hline Mean outcome & 0.819 & 0.819 \\
\hline $\mathrm{N}$ & 1972 & 1972 \\
\hline $\begin{array}{l}\text { Panel D: Log of Average Social } \\
\text { Income Transfers, 2001-2012 }\end{array}$ & OLS & IV \\
\hline Waist-hip ratio & $\begin{array}{l}2.391^{* *} \\
(1.107)\end{array}$ & $\begin{array}{c}37.651 \\
(25.214) \\
\end{array}$ \\
\hline F-statistics & & 5.49 \\
\hline Mean outcome & 5.585 & 5.585 \\
\hline $\mathrm{N}$ & 1972 & 1972 \\
\hline
\end{tabular}

Notes: Waist-hip ratio is measured in 2001. Earnings are measured as the log of average earnings over the period 2001-2012. Employment is measured as the average share of employment years over the period 2001-2012. Indicator for social income transfers equals one for those who have received social security transfers at least once during 2001-2012. Social income transfers are measured as the log of average transfers over the period 2001-2012. The mean values for the dependent variables are reported. All models include controls for the birth month and birth year effects. Gender, height (2001), and parental education (1980) are also controlled for in all models. The instrument used in the IV models is the waist-hip ratio risk score, based on genetic markers. Angrist-Pischke multivariate F-tests of excluded instrument are reported for the IV models. Heteroscedasticity-robust standard errors are reported in parentheses: *statistically significant at the 0.10 level; **at the 0.05 level; *** at the 0.01 level. 
Appendix Table A10:

Reduced form IV estimates with BMI and WHR risk scores

\begin{tabular}{|l|l|l|l|l|}
\hline & $\begin{array}{l}\text { Log of Average } \\
\text { Earnings, 2001- } \\
2012\end{array}$ & $\begin{array}{l}\text { Share of Years } \\
\text { Employed, 2001- } \\
2012\end{array}$ & $\begin{array}{l}\text { Indicator for } \\
\text { Social Income } \\
\text { Transfers, } \\
2001-2012\end{array}$ & $\begin{array}{l}\text { Log of } \\
\text { Average Social } \\
\text { Income } \\
\text { Transfers, } \\
2001-2012\end{array}$ \\
\hline BMI risk score & $\begin{array}{l}-0.011^{*} \\
(0.006)\end{array}$ & $\begin{array}{l}-0.003^{*} \\
(0.002)\end{array}$ & $\begin{array}{l}0.004^{*} \\
(0.002)\end{array}$ & $\begin{array}{l}0.039^{*} \\
(0.018)\end{array}$ \\
\hline WHR risk & -0.011 & $-0.004^{*}$ & 0.005 & $0.049^{*}$ \\
score & $(0.008)$ & $(0.002)$ & $0.004)$ & $(0.027)$ \\
\hline & & & & \\
\hline Mean outcome & 9.863 & 0.857 & 0.821 & 5.601 \\
\hline $\mathrm{N}$ & 2029 & 2053 & 2029 & 2029 \\
\hline
\end{tabular}

Notes: Earnings are measured as the log of average earnings over the period 2001-2012. Employment is measured as the average share of employment years over the period 2001-2012. Indicator for social income transfers equals one for those who have received social security transfers at least once during 2001-2012. Social income transfers are measured as the log of average transfers over the period 20012012. The mean values for the dependent variables are reported. All models include controls for the birth month and birth year effects. Gender, height, and parental education (1980) are also controlled for in all models. Heteroscedasticity-robust standard errors are reported in parentheses: *statistically significant at the 0.10 level; **at the 0.05 level. 